\title{
Pelatihan Pembuatan Laporan Keuangan Bagi UMKM Sebagai Informasi Untuk Pengambilan Keputusan
}

\author{
Sila Ninin Wisnantiasri \\ Universitas Pembangunan Jaya, sila.wisnantiasri@upj.ac.id \\ Irma Paramita Sofia \\ Universitas Pembangunan Jaya, irma.paramita@upj.ac.id \\ Fitriyah Nurhidayah \\ Universitas Pembangunan Jaya, fitriyah.nurhidayah@upj.ac.id \\ Karsam Sunaryo \\ Universitas Pembangunan Jya, karsam.sunaryo@ upj.ac.id
}

\begin{abstract}
The purpose of this dedication for Pisangan Village Community through financial statement training for small business in collaboration with partners of Citra Kencana Community is to improve the understanding of partners in making financial report especially income statement. The problem facing partners is not mastering how to create a correct financial statement. The financial statements can be used by partners as a benchmark of business performance and business financial analysis tools. Therefore, the methods used in this activity are: (1) convey material about basic concepts of accounting, (2) convey material about components of income statement, (3) provide business simulation and recording financial statements through educational game business accounting (4) the practice of preparing the business income statement and analysis by the entrepreneur, (5) advising / consulting the profit-loss statement. Besides, regression test is done through event study approach to know the impact of training for knowledge of financial report objectives and understanding of financial reporting from the community after getting the training. The result of this activity is increasing both knowledge and understanding of society in making financial report. This is shown by the direction of a positive and significant relationship between training with community knowledge and understanding.
\end{abstract}

Keywords: Financial statement, Small entrepreneurship, Business analysis

PENDAHULUAN

\section{Analisis Situasi}

Pada saat ini pemerintah sedang menggalakkan program kewirausahaan pada masyarakat umum, mahasiswa dan pemuda karena dapat menyerap tenaga kerja lebih banyak daripada BUMN maupun swasta tanpa memerlukan

Available at

http://journal.unj.ac.id/unj/index.php/jpm 
keahlian profesional tertentu atau pendidikan yang tinggi. Dalam hal ini, perguruan tinggi tentunya berperan aktif dalam mendorong pembangunan ekonomi Indonesia melalui dukungan nyata terhadap tumbuhnya wirausahawan-wirausahawan mandiri, salah satunya dengan melakukan pengabdian masyarakat pada bisang terkait. Masyarakat umum yang dimaksudkan salah satunya berasal dari kalangan perempuan, baik itu perempuan bekerja di sektor formal maupun ibu rumah tangga.

$$
\text { Paguyuban Citra Kencana }
$$

(Pagucika) merupakan perkumpulan warga yang terdiri dari 86 kepala keluarga yang berdomisili di Kelurahan Pisangan, Kecamatan Ciputat Timur, Kota Tangerang Selatan Provinsi Banten. Menurut informasi dari Koordinator Pemberdayaan Wanita Pagucika, bahwa sekitar $75 \%$ warga memiliki usaha.

Partisipasi warga yang mengikuti kegiatan ini yaitu 33 peserta. Sebagian besar usaha tersebut dijalankan oleh kalangan wanita. Pemilik usaha paling banyak didominasi oleh ibu-ibu yang memiliki usia 30-40 tahun sebesar 44\% kemudian disusul kalangan usia 40-60

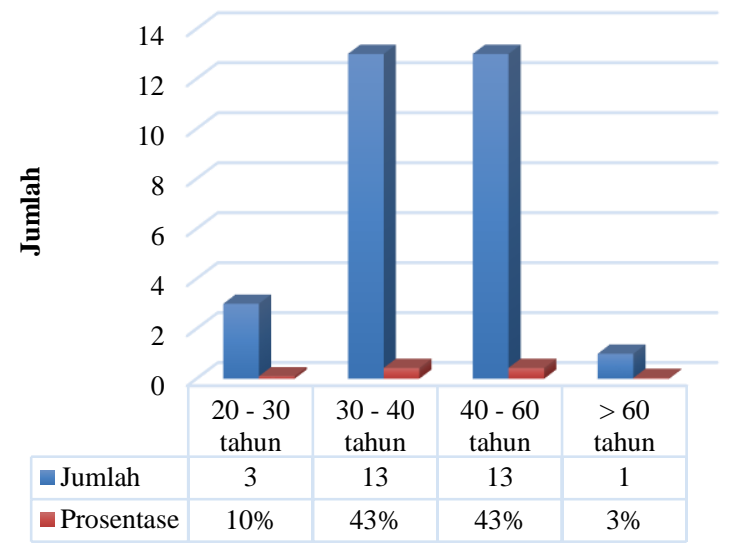

Gambar 1. Jumlah peserta berdasarkan usia

Kegiatan wirausaha bagi ibu-ibu bukan hanya dianalogikan sebagai kegiatan penopang ekonomi keluarga tapi juga sebagai lifestyle di kalangan wanita. Selain untuk menambah penghasilan keluarga, ibu-ibu melakukan kegiatan wirausaha juga sebagai wujud aktualisasi diri khususnya bagi ibu-ibu yang tidak memiliki pekerjaan di sektor formal. Dari segi pendidikan hampir separuh peserta sudah menempuh pendidikan tinggi jenjang $\mathrm{S} 1$ sebesar $47 \%$ sedangkan yang lainnya SD, SMA dan jenjang S2. Dari profil tersebut, dapat diambil kesimpulan bahwa sebagian peserta kegiatan memiliki latar belakang pendidikan yang cukup tinggi sehingga dapat memudahkan dalam penyampaian materi. 


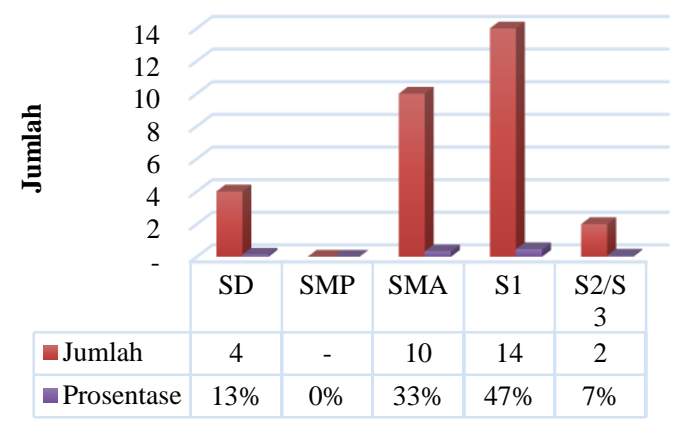

Gambar 2. Jumlah peserta kegiatan berdasarkan pendidikan

Adapun jenis usaha makanan dan minuman yang paling banyak dilakukan sebesar 36\%, jual beli kebutuhan rumah tangga sebesar $24 \%$, sedangkan usaha lainnya sebesar $40 \%$ seperti usaha konveksi, IT, perkebunan, jasa kecantikan, jasa keuangan dll. Data ini menunjukkan bahwa sebagian besar peserta kegiatan menjalankan usaha rumah tangga yaitu makanan dan minuman dan kebutuhan rumah tangga. Bahkan, sebesar $83 \%$ tidak memiliki karyawan atau dikerjakan oleh pemilik.

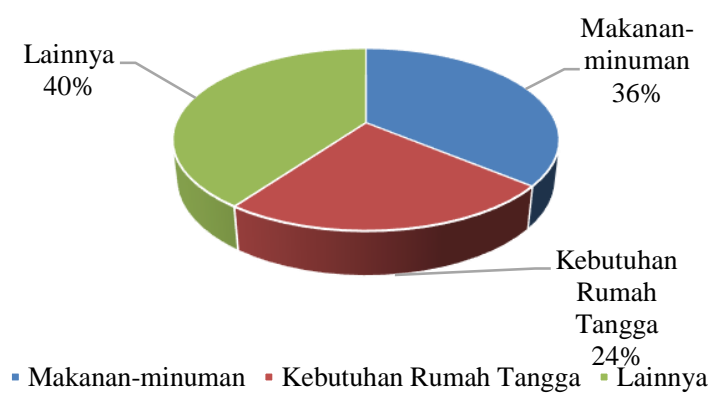

Gambar 3. Jumlah peserta kegiatan berdasarkan bidang usaha

Available at

http://journal.unj.ac.id/unj/index.php/jpm

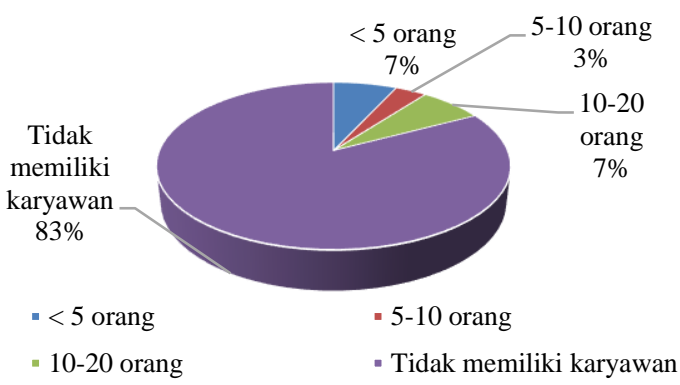

Gambar 4. Jumlah peserta kegiatan berdasarkan jumlah karyawan

Berdasarkan data penghasilan, jumlah penghasilan per bulan dari usaha peserta sebesar $81 \%$ berada pada interval 0-5 juta per bulan, 4\% berada pada interval 5-20 juta per bulan dan sebesar $15 \%$ berpenghasilan lebih dari 20 juta per bulan. Jika melihat dari klasifikasi menurut Undang-undang No 20 tahun 2008 tentang Usaha Mikro, Kecil dan Menengah, maka peserta kegiatan dapat digolongkan sebagai usaha mikro dan kemungkinan digolongkan sebagai usaha kecil untuk penghasilan di atas 20 juta per bulan.

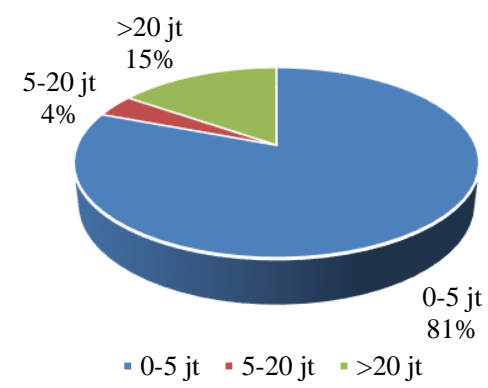

Gambar 5. Jumlah peserta berdasarkan penghasilan per bulan 
Ibu-ibu yang memiliki usaha ini cenderung melakukan kegiatan wirausaha tanpa perencanaan yang matang. Kebanyakan mereka melakukan jual beli spontan dan arus kas dari jual beli tersebut tercampur pengelolaannya dengan kas rumah tangga sehingga seringkali membingungkan. Selain itu, mereka juga jarang membuat laporan yang tertib mengenai hasil usaha tersebut. Dalam jangka panjang, jika tidak dikelola dengan baik, maka usahausaha mereka tidak bisa berkelanjutan.

Sebagian besar usaha tersebut dijalankan oleh kalangan wanita. Usaha tersebut dijalankan oleh wanita yang berprofesi sebagai ibu rumah tangga maupun ibu pekerja formal. Ibu-ibu yang memiliki usaha kecil, biasanya memasarkan produknya ke rekan-rekan dan tetangga melalui sarana komunikasi online atau pada saat forum-forum silaturahmi berkala seperti pengajian, arisan atau pertemuan warga sedangkan yang lainnya sudah memiliki ruko atau kantor untuk menjalankan usaha.

\section{Perumusan Masalah}

Pada usaha kecil, wirausahawan seringkali mengalami banyak kendala bahkan jika mereka sudah memiliki

\section{DOI: https://10.21009/JPMM.002.1.05}

pengetahuan usaha yang cukup. Apalagi jika kegiatan usaha ini dijalankan oleh ibu-ibu yang sebenarnya memiliki tugas yang lain yaitu mengurus keluarga atau bekerja pada sektor formal. Jika tidak dikelola dengan baik, maka usaha-usaha ini tidak bisa berkembang dan memiliki sumbangsih bagi ekonomi negara, bahkan bisa mendatangkan kerugian bagi pelaku usaha tersebut.

Menurut Zimmerer (2008) salah satu kesalahan fatal kewirausahaan adalah kegagalan mengembangkan perencanaan stategis. Perencanaan yang kurang matang bisa terjadi karena mereka melakukan jual beli secara spontan, hanya melakukan jual-beli pada saat-saat tertentu, membeli barang dagangan atau investasi dalam jumlah banyak tanpa memikirkan kemampuan keuangan yang ada.

Mereka cenderung mengikuti kata hati dan tren yang ada di kalangan sosial, tanpa memikirkan bagaimana cara memasarkan, atau bagaimana jika barang tidak laku. Dalam menentukan harga jual, juga seringkali hanya berpedoman pada harga beli dari produk tersebut, tanpa mempertimbangkan biaya overhead yang dikeluarkan tapi 
tidak disadari. Tanpa strategi yang jelas, usaha tidak memiliki dasar yang berkesinambungan untuk menciptakan keunggulan.

Kesalahan lain yang dimiliki oleh pelaku usaha itu salah satunya adalah di bidang pengelolaan keuangan. Keberhasilan bisnis memerlukan kendali keuangan yang layak terutama dalam hal arus kas. (Zimmerer, 2008). Ibu-ibu yang dalam hal ini yang dimaksud sebagai pelaku usaha sering mencampurkan uang kas yang digunakan untuk usaha dan uang kas yang digunakan untuk keperluan rumah tangga. Sehingga ketika produk mereka sudah habis terjual, mereka kadang tidak bisa melakukan pemesanan kembali karena uang habis untuk kebutuhan keluarga. Jika arus barang berhenti, maka otomatis kegiatan usaha tersebut juga berhenti.

Kendala yang sangat vital lainnya adalah ketidakmampuan dalam membuat laporan keuangan dengan benar. Kebanyakan dari mereka mengasumsikan kas masuk sebagai pendapatan dan kas keluar sebagai biaya. Padahal menurut pemahaman akuntansi, hal tersebut tidak benar dan
DOI: $\underline{\text { https://10.21009/JPMM.002.1.05 }}$

menyebabkan informasi yang kurang tepat. Apalagi yang terjadi pada ibu-ibu yang mana sebagian biayanya jadi satu dengan rumah tangga, seperti biaya tempat yang memakai rumah sendiri, biaya listrik, pemakaian peralatan rumah tangga untuk keperluan usaha dan lainlain. Hal ini sangat berbahaya terutama jika mereka berusaha untuk melakukan usaha mandiri terpisah dari rumah tangga dan terkejut ternyata masih banyak pengeluaran-pengeluaran yang terjadi.

Berdasarkan

pentingnya pembuatan laporan keuangan tersebut, hanya sekitar $29 \%$ pelaku usaha yang telah membuat pembukuan, sedangkan peserta kegiatan yang tidak melakukan pembukuan sebesar 71\%. Alasan terbesar peserta tidak melakukan pembukuan adalah karena tidak menguasai cara pembuatan laporan keuangan sebesar 60\%, sedangkan sisanya yaitu sebesar $40 \%$ beralasan bahwa mereka tidak membutuhkannya. Hal ini dapat dikarenakan skala usaha yang masih terlalu kecil sehingga belum merasakan kebutuhan terhadap laporan keuangan, dan berfokus pada pencapaian omzet usaha.

\section{Available at}




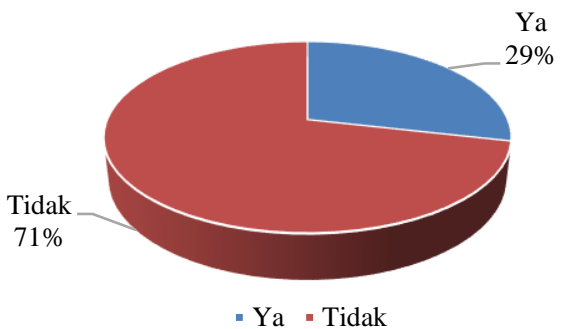

Gambar 6. Pelaksanaan pembukuan usaha

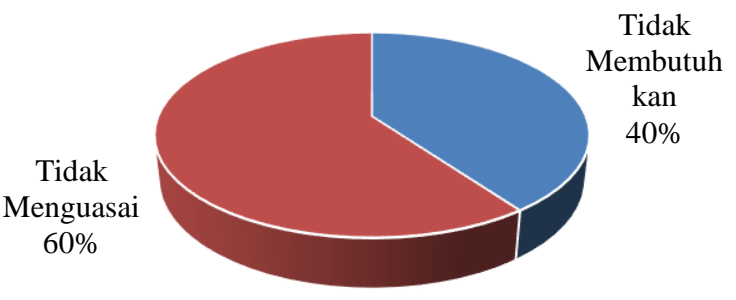

- Tidak Membutuhkan - Tidak Menguasai

Gambar 7. Alasan tidak melakukan pembukuan usaha

\section{Tujuan}

Permasalahan-permasalahan di atas selalu menjadi pembahasan karena menjadi momok bagi pelaku usaha kecil terutama pada kalangan ibu-ibu. Oleh karena itu, mengacu pada program pemerintah di bidang kewirausahawan, maka disepakati untuk melaksanakan suatu pengabdian masyarakat dengan tujuan meningkatkan pengetahuan pelaku usaha pemahaman pelaku usaha mengenai tujuan laporan keuangan dan pemahaman dalam pembuatan laporan keuangan.

Available at

http://journal.unj.ac.id/unj/index.php/jpm
DOI: $\underline{\text { https://10.21009/JPMM.002.1.05 }}$

\section{Manfaat}

Berdasarkan tujuan tersebut, kegiatan ini diharapkan bermanfaat bagi masyarakat di Kelurahan Pisangan Kecamatan Ciputat terutama Paguyuban Citra Kencana sehingga memiliki pengetahuan dan pemahaman dalam pembuatan laporang keuangan. Apabila pelaku usaha sudah dapat membuat laporan keuangan mandiri dan menganalisis laporan keuangan tersebut, maka dapat dijadikan informasi dalam pengambilan keputusan bisnis yang tepat.

\section{KAJIAN TEORITIK}

Pentingnya membuat Laporan Keuangan

Laporan keuangan merupakan informasi yang dibutuhkan pengguna sebagai bahan pertimbangan dalam pengambilan keputusan (Kieso, 2011). Terdapat 2 jenis pengguna laporan keuangan yaitu pengguna internal dan pengguna eksternal. Pengguna internal adalah manajer yang merencanakan dan mengelola bisnis. Laporan keuangan berguna untuk bahan perbandingan alternatif operasi binis, simulasi pendapatan untuk strategi penjualan 
tertentu dan perkiraan kebutuhan di tahun-tahun mendatang. Untuk dapat memperkiraan kebutuhan mendatang, akan digunakan analisis prospektif melalui proses proyeksi (Subramanyam, 2010).

Sedangkan untuk pengguna eksternal berasal dari luar perusahaan yang membutuhkan informasi keuangan seperti investor dan kreditur. Sebelum pengguna eksternal mengambil keputusan investasi di bisnis tersebut, biasanya mereka melakukan studi kelayakan bisnis untuk menghindari kerugian (Halim, 2009). Salah satu hal yang dilihat oleh pengguna laporan keuangan adalah laporan keuangan yang dapat mencerminkan jumlah aset yang dimiliki, kemampuan menghasilkan laba dll.

Dari hasil survey yang dilakukan sebelum dilakukan pelatihan, sebagian besar peserta kegiatan, sebesar $67 \%$ sebenarnya mengetahui tujuan dari pembuatan laporan keuangan, 17\% sangat mengetahui sedangkan sisanya kurang mengetahui dan tidak mengetahui. Namun meskipun mengetahui tujuan laporan keuangan, hanya sedikit peserta yang yang

Available at

http://journal.unj.ac.id/unj/index.php/jpm melakukan pembukuan yaitu $29 \%$ seperti yang ditunjukkan pada Gambar 6.

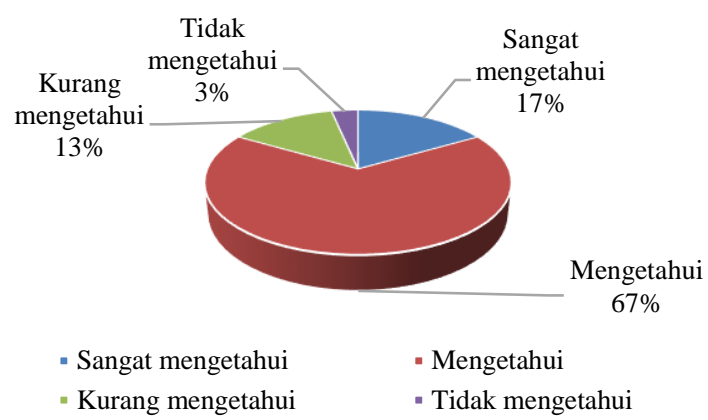

Gambar 8. Pengetahuan peserta kegiatan tentang tujuan laporan keuangan

Laporan keuangan terdiri dari laporan posisi keuangan, laporan laba rugi, laporan perubahan modal, laporan arus kas dan catatan atas laporan keuangan. Laporan tersebut memiliki fungsi dan bentuk penyajian yang berbeda namun saling berhubungan satu sama lain. Pada pengabdian masyarakat kali ini, laporan laba rugi adalah laporan yang pertama kali diajarkan, selanjutnya adalah laporan arus kas dan neraca. Hal ini dikarenakan laporan laba rugi merupakan salah satu informasi yang penting untuk menilai kinerja usaha. Dengan laporan tersebut, mitra dapat mengetahui laba atau rugi dalam usahanya sehingga berdasarkan informasi tersebut, pelaku usaha dapat membuat berbagai perencaaan strategis 
Laporan keuangan terdiri dari laporan posisi keuangan, laporan laba rugi, laporan perubahan modal, laporan arus kas dan catatan atas laporan keuangan. Laporan tersebut memiliki fungsi dan bentuk penyajian yang berbeda namun saling berhubungan satu sama lain.

Pada pengabdian masyarakat kali ini, laporan laba rugi adalah laporan yang pertama kali diajarkan, selanjutnya adalah laporan arus kas dan neraca. Hal ini dikarenakan laporan laba rugi merupakan salah satu informasi yang penting untuk menilai kinerja usaha. Dengan laporan tersebut, mitra dapat mengetahui laba atau rugi dalam usahanya sehingga berdasarkan informasi tersebut, pelaku usaha dapat membuat berbagai perencaaan strategis.

\section{Laporan Laba Rugi}

Laporan laba rugi adalah laporan untuk mengukur keberhasilan atau keuntungan operasi perusahaan pada periode tertentu (Kieso, 2011). Pertama, laporan laba rugi menampilkan penjualan, kemudian diikuti dengan beban. Setelah itu baru dapat dihitung laba atau rugi dari bisnis. Jika penjualan
DOI: $\underline{\text { htps://10.21009/JPMM.002.1.05 }}$

melibihi beban, maka disebut laba. Jika beban melebihi penjualan disebut rugi.

\section{Laporan Arus Kas}

Laporan arus kas menyediakan informasi mengenai uang kas yang diterima dan dibayarkan pada periode waktu tertentu (Kieso, 2011). Dalam pernyataan laporan arus kas, terdiri dari arus kas dari aktivitas operasi, aktivitas investasi dan aktivitas pendanaan.

\section{Neraca}

Laporan posisi keuangan, yang dikenal sebagai neraca, merupakan laporan yang berisi pernyataan posisi keuangan yaitu aset, utang dan modal (Kieso, 2011). Perusahaan menampilkan posisi aset terlebih dahulu kemudian utang dan modal. Jumlah aset harus sama dengan utang ditambah modal.

\section{Pendapatan}

Pendapatan adalah kenaikan modal yang berasal dari kegiatan bisnis (Kieso, 2011). Secara umum, pendapatan didapatkan dari penjualan barang dagangan, jasa, penyewaan properti dan peminjaman uang. Penjualan nantinya akan menaikkan jumlah aset bisnis dan menambah modal perusahaan. 


\section{Beban}

Beban adalah biaya konsumsi aset atau jasa yang digunakan dalam proses menghasilkan pendapatan (Kieso 2011). Beban menurunkan modal yang dihasilkan dari operasi bisnis. Seperti pendapatan, beban memiliki banyak bentuk seperti biaya bahan baku (tepung, saus, tomat dll), beban gaji dan upah, beban utilitas (listrik, gas, air), beban telepon, beban pengiriman, beban sewa, beban bunga dll.

\section{Harga Pokok penjualan}

Harga pokok penjualan adalah biaya barang yang dijual selama periode tertentu (Kieso, 2011). Beban ini berhubungan langsung dengan pendapatan dari penjualan barang. Harga pokok penjualan terdiri dari bahan baku yang digunakan ditambah beban tenaga kerja langsung dan beban tidak langsung.

\section{Analisis Prospektif}

Analisis laporan keuangan yang digunakan dalam pengabdian masyarakat ini adalah analisis prospektif yang dapat dilakukan setelah laporan keuangan historis yang mencerminkan kinerja ekonomis perusahaan selesai dibuat dengan akurat. Analisis prospektif meliputi peramalan posisi keuangan (neraca), laporan laba rugi, dan laporan arus kas. Selain itu analisis ini dapat juga digunakan untuk menguji ketepatan rencana startegis perusahaan (Subramanyam, 2011).

Salah satu metode analisis propektif ini melalui proses proyeksi dimulai dari laporan laba rugi, diikuti dengan laporan posisi keuangan (neraca), dan laporan arus kas. Pada pengabdian masyarakat ini, tim berfokus pada proses proyeksi laporan laba rugi dengan mempertimbangkan tingkat urgensitas dan kemampuan peserta untuk menyerap materi. Proses proyeksi dimulai dengan proyeksi penjualan yang diharapkan, kemudian laba kotor diproyeksi dan beban-beban penjualan dan operasional.

\section{MATERI DAN METODE}

\section{Kerangka Pemecahan Masalah}

Dalam pengabdian masyarakat ini, peserta akan diberikan pra pelatihan berupa pengisian kuesioner survey awal mengenai pemahaman pembuatan laporan keuangan, pelatihan, pendampingan atau konsultasi pembuatan laporan keuangan, pelatihan 
lanjutan, simulasi usaha dan pembuatan laporan keuangan dan analisis laporan keuangan.

\section{Realisasi Pemecahan Masalah}

1. Pra pelatihan yaitu survey mengenai tingkat pengetahuan tujuan laporan keuangan dan pemahaman pembuatan laporan keuangan pelaku usaha menggunakan instrumen kuesioner yang diisi menggunakan skala likert 1-4.

2. Pelatihan pertama, penyampaian materi mengenai komponen laporan laba rugi. Pemateri menjelaskan tentang apa itu penjualan, harga pokok penjualan, persedian bahan baku, biaya tenaga kerja langsung, biaya produksi tidak langsung (Lanen, 2017). Selanjutnya, peserta diberikan mengenai contoh tentang biaya-biaya tersebut dan mengapa harus dihitung dan dimasukkan ke laporan laba rugi. Setelah mengetahui komponen-komponen laporan laba rugi, materi selanjutnya adalah menghitung laba kotor dan laba bersih. Hasil laba/rugi tersebut merupakan cerminan kinerja usaha.

3. Kegiatan konsultasi berupa bantuan pendampingan tutorial mengisi format laporan laba/rugi dari usaha yang dijalankan. Pendampingan dilakukan selama 3 bulan untuk melihat kemampuan peserta dalam membuat laporan laba rugi secara mandiri.

4. Pelatihan lanjutan yaitu penyampaian materi pentingnya akuntansi, jenisjenis laporan keuangan beserta fungsinya, format laporan keuangan, basis pencatatan akuntansi, konsepkonsep akuntansi, pengendalian internal dan tata cara pencatatan hingga laporan. Selain itu juga diberikan materi mengenai anggaran dan realisasi agar pelaku usaha dapat melakukan analisa dan evaluasi usaha mereka.

5. Simulasi menjalankan transaksi usaha dan pembuatan laporan keuangan, laporan laba rugi, neraca dan arus kas disertai dengan pengendalian internal yang baik (Romney 2012)

6. Analisis laporan keuangan dengan analisis prospektif melalui proses proyeksi (Subranyaman, 2011). Kegiatan ini berfokus pada analisis proyeksi laporan laba rugi dengan pertimbangan urgensitas dan 
kemampuan peserta kegiatan dalam menyerap materi.

7. Evaluasi keberhasilan program melalui survey sesudah pelatihan mengenai tingkat pengetahuan tujuan laporan keuangan dan tingkat pemahaman mengenai pembuatan laporan keuangan.

\section{Khalayak Sasaran}

Khalayak sasaran dalam kegiatan ini adalah Ibu-ibu pelaku usaha yang tergabung dalam Paguyuban Citra Kencana. Teknik penarikan sampel yang digunakan adalah purposive sampling. Sampel yang diambil adalah 30 dari 33 orang yang mengikuti pelatihan pembuatan laporan keuangan ini.

\section{Metode Kegiatan}

Metode kegiatan dalam pengabdian masyarakat ini adalah penyampaian materi, pendampingan dan simulasi pembuatan laporan keuangan. Kegiatan ini merupakan dilaksanakan agar pelaku usaha memiliki pemahaman pembuatan laporan keuangan yang nantinya digunakan untuk merumuskan strategi usaha yang tepat melalui informasi dari laporan keuangan tersebut.
DOI: $\underline{\text { htps://10.21009/JPMM.002.1.05 }}$

Evaluasi akan dilakukan dengan melihat pengaruh yang terjadi setelah dilaksanakannya pelatihan terhadap pengetahuan tujuan laporan keuangan dan pemahaman pembuatan laporan keuangan oleh pelaku usaha. Untuk mengevaluasi mengenai pengetahuan pelaku usaha mengenai tujuan laporan keuangan, pengukuran digunakan skala likert 1-4 yaitu (1) tidak mengetahui, (2) kurang mengetahui, (3) mengetahui, (4) sangat mengetahui. Sedangkan evaluasi mengenai pemahaman pembuatan laporan keuangan, pengukuran dilakukan dengan skala likert 1-4 yaitu (1) tidak memahami, (2) kurang memahami, (3) paham, (4) sangat memahami.

Untuk menghitung skor tingkat pengetahuan tujuan laporan keuangan dan pemahaman pembuatan laporan keuangan, maka digunakan formulasi berikut untuk menghitung skor hitung :

Persamaan 1 :

Skor Hitung $=\frac{\text { Skor Survey }}{\text { Skor Maksimal }} \times 100 \%$

Kemudian skor hitung akan diintrepretasikan berdasarkan tabel berikut ini : 
Tabel 1. Intrepretasi kuesioner survey

\begin{tabular}{|c|l|}
\hline \multicolumn{1}{|c|}{ Skor } & \multicolumn{1}{|c|}{ Kriteria } \\
\hline $0 \%-20 \%$ & Sangat lemah \\
\hline $21 \%-40 \%$ & Lemah \\
\hline $41 \%-60 \%$ & Cukup \\
\hline $61 \%-80 \%$ & Kuat \\
\hline $81 \%-100 \%$ & Sangat Kuat \\
\hline
\end{tabular}

(Riduwan, 2012)

Pengujian selanjutnya dari data hasil survey yang dikumpulkan adalah uji regresi dengan pendekatan studi peristiwa (Sukirno DS, 2003) untuk mengetahui pengaruh pelatihan bagi peningkatan pengetahuan tujuan laporan keuangan dan pemahaman pembuatan laporan keuangan oleh pelaku usaha sebelum dan sesudah dilakukan pelatihan.

Adapun persamaan yang digunakan untuk menguji tingkat pengetahuan tujuan laporan keuangan adalah sebagai berikut :

Persamaan 2 :

$$
\mathrm{Yi}=\alpha+\beta \mathrm{Di}+\varepsilon
$$

dimana :

$\mathrm{Yi}=$ nilai skor pengetahuan

$\mathrm{D}=$ variabel dummy yaitu, $(1=$ setelah,

$0=$ sebelum)

$\alpha=$ konstanta

$\beta=$ slope
DOI: $\underline{\text { https://10.21009/JPMM.002.1.05 }}$

$\varepsilon=$ error

Sedangkan persamaan yang digunakan untuk menguji tingkat pemahaman pembuatan laporan keuangan adalah sebagai berikut :

Persamaan 3 :

$$
Y i=\propto+\beta D i+\varepsilon
$$

dimana :

$\mathrm{Yi}=$ nilai skor pemahaman

$\mathrm{D}$ = variabel dummy yaitu, $(1=$ setelah, $0=$ sebelum)

$\alpha=$ konstanta

$\beta=$ slope

$\varepsilon=$ error

\section{HASIL DAN PEMBAHASAN}

\section{Deskripsi Kegiatan}

Sebagian masyarakat di Pagucika memiliki usaha yang tergolong dalam usaha mikro dan kecil. Berdasarkan informasi yang diperoleh bahwa kebutuhan mitra adalah bagaimana cara mengukur hasil usaha mereka maka dilakukan pengabdian masyarakat ini.

Pelatihan pertama dilaksanakan pada hari Kamis 21 Desember 2017, tepat pukul 09.30 sampai selesai. Acara dimulai dengan registrasi dan pengisian kuesioner berupa data peserta serta pengetahun dan pemahaman awal. 
Materi yang pertama kali disampaikan adalah mengenai komponen-kompone laporan laba rugi terutama harga pokok penjualan tentang apa itu penjualan, harga pokok penjualan, persedian bahan baku, biaya tenaga kerja langsung, biaya produksi tidak langsung (Lanen, 2017). Selanjutnya, peserta diberikan mengenai contoh tentang biaya-biaya tersebut dan mengapa harus dihitung dan dimasukkan ke laporan laba rugi.

Pada sesi tanya jawab, terjadi interaksi yang sangat menarik. Beberapa peserta baru menyadari bahwa ternyata dalam usaha, banyak biaya-biaya yang harus diperhitungkan, terutama biayabiaya yang pengeluarannya tercampur dengan pengeluaran individu. Biaya yang tidak diperhitungkan seperti pemakaian kendaraan pribadi, biaya listrik yang tercampur dengan rumah, biaya tenaga memasak dan tenaga penjualan dll.

Ketidaktepatan dalam menghitung laporan laba rugi ini menyebabkan mitra kurang tepat dalam mengambil keputusan bisnis seperti penentuan harga jual, proyeksi biaya pokok, proyeksi laba yang diharapkan, strategi promosi,
DOI: $\underline{\text { https://10.21009/JPMM.002.1.05 }}$

kemungkinan ekspansi dan keputusan bisnis lainnya.

Setelah materi selesai disampaikan, tim memberikan gambaran mengenai perhitungan mulai dari penjualan kemudian biaya pokok penjualan dan biaya administrasi dan umum sehingga menghasilkan perhitungan laba kotor dan laba bersih. Banyak dari mitra yang masih kesulitan mengklasifikasikan beban-beban karena jenis usaha yang beragam. Usaha dagang seperti jual beli makanan dan kebutuhan rumah tangga memiliki format laporan laba rugi yang berbeda dengan usaha produksi. Untuk mencari laba kotor, komponen harga pokok penjualan terdiri dari saldo awal persediaan, jumlah pembelian dan saldo akhir persediaan.

Sedangkan untuk usaha produksi seperti katering makanan dan minuman dimana terjadi proses pengolahan dari bahan baku menjadi barang jadi memiliki tingkat kesulitan yang lebih tinggi karena jenis persediaan bermacam-macam dan terdapat barang setengah jadi.

Setelah dilakukan pelatihan pertama mengenai komponenkomponen laporan keuangan dan cara 
membuat laporan laba rugi, tim memberikan konsultasi pendampingan di luar pendampingan. Konsultasi dilakukan dengan jadwal tentatif sesuai kesepakatan dengan mitra. Selama periode pengabdian masyarakat, tim memberikan 2 kali konsultasi yaitu tgl 21 Februari dan 15 April 2018. Kegiatan konsultasi berupa bantuan turotial mengisi format laporan laba/rugi dari usaha yang dijalankan.

Dalam tahap ini, hanya sedikit peserta yang berhasil membuat laporan laba/rugi. Kurang berhasilnya pembuatan laporan laba/rugi ini dikarenakan pelaku usaha tidak memiliki waktu untuk melakukan pencatatan karena masih fokus untuk melakukan penjualan dan produksi. Hal ini sesuai dengan profil pelaku usaha yaitu masih usaha mikro dan tidak memiliki karyawan sehingga semua proses dikerjakan sendiri. Selain itu, peserta merasa sulit dan rumit untuk membuat laporan karena banyak sekali komponenkomponen yang harus dicatat.

Berdasarkan hasil evaluasi pada tahap konsultasi, tim pengabdian masyarakat merundingkan bagaimana cara membuat pelaku mengerti tentang

Available at

http://journal.unj.ac.id/unj/index.php/jpm laporan keuangan dengan metode sederhana, menyenangkan dan tidak rumit. Oleh karena itu, dilakukan eksperimen untuk membuat alat peraga sederhana berupa permainan wirausaha yang tujuan akhirnya adalah pembuatan laporan laba/rugi. Alat peraga ini akan diberikan kepada peserta pada saat pelatihan lanjutan.

Pelatihan lanjutan dilaksanakan pada hari Jumat, 27 April 2018. Materi yang diberikan yaitu pentingnya akuntansi, jenis-jenis laporan keuangan beserta fungsinya, format laporan keuangan, basis pencatatan akuntansi, konsep-konsep akuntansi, pengendalian internal dan tata cara pencatatan hingga laporan. Selain itu juga diberikan materi mengenai anggaran dan realisasi agar pelaku usaha dapat melakukan analisa dan evaluasi usaha mereka.

Setelah penyampaian materi yang diberikan kurang lebih selama 30 menit, maka dilanjutkan dengan sesi permainan bisnis. Adapun permainan edukatif ini menggabungkan antara strategi usaha dengan pelaporan akuntansi untuk usaha. Permainan ini dilakukan secara berkelompok. 
Pada tahap awal, kelompok diberikan modal awal untuk menjalankan usahanya yaitu sejumlah uang tertentu dan persediaan barang dagangan. Sebelum mulai permainan, kelompok diminta untuk membuat neraca awal untuk kekayaan yang dimiliki. Dalam tahap ini, pelaku usaha belajar cara membuat laporan keuangan yaitu neraca.

Langkah selanjutnya adalah memulai transaksi usaha. Kelompok akan diberikan beberapa transaksi usaha seperti penjualan, pembelian dan pembayaran biaya operasional. Setiap transaksi yang terjadi langsung dicatat pada formulir yang disediakan.

Dalam tahap ini, kelompok diberikan pengalaman praktik mengenai bagaimana melakukan pencatatan setiap transaksi, dokumentasi transaksi. Selain itu kelompok akan belajar mengenai strategi bisnis seperti bagaimana mengelola persediaan sehingga pada saat ada pelanggan, barang siap untuk dijual. Kemudian pembelajaran selanjutnya adalah mengatur arus kas masuk dan keluar, kapan melakukan pembelian dan juga ketelitian dalam menyimpan uang kas. Jika tidak dilakukan dengan teliti, uang kas di tangan dan hasil catatan akan berbeda.

Dalam permainan ini, peserta dibagi menjadi 3 kelompok usaha yang mana di dalam kelompok, anggota memiliki peran masing-masing. Pembagian peran ini ditujukan agar peserta menyadari pentingnya pemisahaan tugas jika mereka memiliki karyawan. Pemisahan tugas anggota kelompok dilakukan sesuai dengan prinsip pengendalian internal untuk mencegah terjadinya kecurangan pada usaha.

Peran kelompok yang wajib ada yaitu pemimpin usaha sebagai fungsi otorisasi, keuangan dan gudang sebagai fungsi menjaga aset, dan yang terakhir adalah akuntan sebagai fungsi pencatatan sesuai dengan fungsi pengendalian melalui pemisahan tugas (Romney, 2012). Pada saat pelaksanaan permainan, semua anggota kelompok menjalankan peran dan fungsinya masing-masing.

Setelah transaksi penjualan, pembelian dan pembayaran operasional selesai dilaksanakan, maka dokumen transaksi dikumpulkan kemudian diklasifikasikan pada pos-pos yang 
sesuai. Pos-pos tersebut adalah pos-pos yang berkaitan dengan laporan laba rugi yaitu pos penjualan, pembelian, dan beban operasional. Kelompok usaha kemudian memasukkan saldo pos pada format laporan laba/rugi ya telah disediakan.

Pada permainan ini, tidak hanya laporan laba/rugi saja yang diajarkan, namun juga laporan arus kas dan neraca sesuai dengan format Kieso, 2010 yang disederhanakan. Pada akhir permainan, tim meberikan penghargaan berupa bingkisan bagi kelompok usaha yang menghasilkan laba paling besar dan dapat menyelesaikan laporan laba/rugi, laporan arus kas dan neraca dengan benar.

Ketika peserta sudah bisa membuat laporan keuangan dengan benar, materi selanjutnya adalah menggunakan informasi yang tertera dalam laporan keuangan khususnya laporan laba/rugi untuk membuat analisa bisnis. Tim memberikan arahan tentang bagaimana menentukan target usaha yang tepat sesuai kondisi keuangan yang ada berdasarkan analisis preopektif melalui proses proyeksi (Subramanyam, 2011). Pada mulannya pelaku usaha diminta untuk menentukan target laba yang diinginkan. Kemudian berikutnya mereka akan menghitung berapa penjualan yang harus dicapai dan penghematan beban operasional apa saja yang mungkin dilakukan.

Dengan selesainya pembuatan analisa keuangan, maka rangkaian acara pengabdian masayarakat di Pagucika sudah selesai dilaksanakan. Kegiatan terakhir yaitu mengisi kuesioner mengenai tingkat pengetahuan dan pemahaman peserta kegiatan setelah dilaksanakan pelatihan.

\section{Hasil Uji Analisis}

Untuk pertanyaan mengenai pengetahuan tujuan laporan keuangan, pengukuran dilakukan dengan skala likert 1-4 yaitu (1) tidak mengetahui, (2) kurang mengetahui (3) mengetahui, (4) sangat mengetahui. Sedangkan untuk mengetahui pengaruh pelatihan terhadap pemahaman pembuatan laporan keuangan, pengukuran juga menggunakan skala likert 1-4 yaitu yaitu (1) tidak memahami, (2) kurang memahami (3) paham, (4) sangat memahami. Adapun hasil dari deskripsi statistik dari kueioner sebelum dan 
sesudah pelatihan ditampilkan pada tabel di bawah ini :

Tabel 2. Uji deskriptif rata-rata

\begin{tabular}{|c|c|c|}
\hline \multirow{2}{*}{ Uji } & \multicolumn{2}{|c|}{ Skor Rata-rata } \\
\cline { 2 - 3 } & Sebelum & Sesudah \\
\hline Pengetahuan & 2,96 & 3,20 \\
\hline Pemahaman & 2,23 & 2,90 \\
\hline
\end{tabular}

Dari hasil statistik deskriptif pengetahun di atas terdapat kenaikan rata-rata pengetahuan peserta kegiatan mengenai tujuan laporan keuangan. Pada awal pelatihan rata-rata nilai pengetahuan adalah 2,96, kemudian di akhir pelatihan nilai pengetahuan naik menjadi 3,2.

Berdasarkan hasil statistik deskriptif pemahaman terdapat kenaikan rata-rata pemahaman peserta kegiatan mengenai pembuatan laporan keuangan. Pada awal pelatihan rata-rata nilai pemahaman adalah 2,23, kemudian di akhir pelatihan nilai skor pemahaman naik menjadi 2,90.

Setelah diketahui skor rata-rata masing-masing pengujian kemudian dicari skor hitung berdasarkan persamaan 1 kemudian diintrepretasikan dengan Tabel 1 dengan hasil sebagai berikut :
Tabel 3. Skor hitung

\begin{tabular}{|c|c|c|}
\hline \multirow{2}{*}{ Uji } & \multicolumn{2}{|c|}{ Skor hitung } \\
\cline { 2 - 3 } & Sebelum & Sesudah \\
\hline Pengetahuan & $74 \%$ & $80 \%$ \\
& (kuat) & (kuat) \\
\hline Pemahaman & $55,75 \%$ & $72,5 \%$ \\
& (cukup) & (kuat) \\
\hline
\end{tabular}

Pada tingkat pengetahuan tujuan laporan keuangan terdapat kenaikan skor hitung dari $74 \%$ menjadi $80 \%$. Meskipun masih berada dalam level yang sama yaitu level kuat, tingkat pengetahuan setelah pengetahuan berada di ambang batas atas level kuat menuju level sangat kuat yaitu $80 \%$. Sedangkan untuk tingkat pemahaman pembuatan laporan keuangan terjadi kenaikan dari 55,75\% menjadi $72,5 \%$ dan terjadi perubahan level dari level cukup menjadi level kuat.

Langkah selanjutnya adalah melakukan uji regresi melalui pendekatan studi peristiwa sebelum dan sesudah pelatihan melalui persamaan 1 dan persamaan 2. Hasil uji regresi ditampilkan dalam tabel di bawah ini :

Tabel 4. Uji Analisis Regresi

\begin{tabular}{|c|c|c|}
\hline Uji & Koefisien & P Sig \\
\hline Pengetahuan & 0,18 & 0,10 \\
\hline Pemahaman & 0,48 & 0,00 \\
\hline
\end{tabular}


Hasil uji regresi mengenai tingkat pengetahuan tujuan laporan keuangan yang dilakukan, menghasilkan koefisien beta adalah positif sebesar 0,17 dengan tingkat signifikansi 0,10 . Hal ini dapat disimpulkan bahwa arah hubungan pelatihan dan pengetahuan terhadap pengetahuan mengenai tujuan laporan keuangan dan signifikan pada level signifikansi 10\% secara uji statistik.

$$
\text { Peserta kegiatan telah }
$$

mengetahui tujuan laporan keuangan. Sesuai dengan Gambar 8, peserta yang sudah mengetahui tujuan laporan keuangan sebesar $67 \%$ dan sangat mengetahui $17 \%$. Angka prosentase ini termasuk cukup tinggi dan data didukung oleh profil pendidikan yang sebagian besar peserta sudah menempuh pendidikan tinggi dengan prosentase $47 \%$ untuk jenjang S1.

Dari hasil uji regresi mengenai tingkat pemahaman yang dilakukan, koefisien beta adalah positif sebesar 0,48 dengan tingkat signifikansi 0,00. Hal ini dapat disimpulkan bahwa arah hubungan pelatihan dan pemahaman pembuatan laporan keuangan positif dan signifikan secara uji statistik.
DOI: https://10.21009/JPMM.002.1.05

Sebelum datang pelatihan, peserta kegiatan belum terlalu paham dalam pembuatan laporan keuangan meskipun mengetahui tujuan laporan keuangan. Angka prosentase pengetahuan yang cukup tinggi tidak membuat pelaku usaha melakukan pencatatan. Hal ini didukung dengan prosentase peserta kegiatan yang melakukan pencatatan/pembukuan hanya sebesar $29 \%$ sedangkan yang tidak membuat laporan keuangan sebesar $71 \%$. Diantara yang tidak membuat laporan keuangan, sebesar $60 \%$ peserta menyatakan bahwa mereka tidak menguasai cara pembuatan laporan keuangan.

Selain menguji kenaikan tingkat pengetahun dan pemahaman pembuatan laporan keuangan, dilakukan survey tentang manfaat dilakukan pelatihan ini bagi pelaku usaha. Hasil survey dapat dilihat pada gambar di bawah ini :

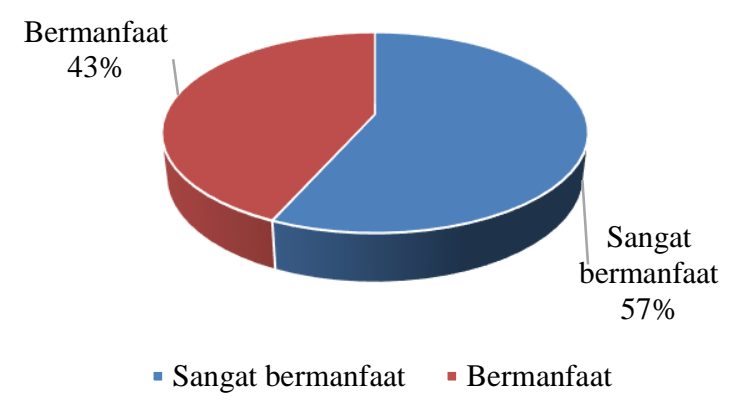

Gambar 9. Manfaat pelatihan 
Hasil survey menyatakan bahwa peserta kegiatan mendapatkan manfaat dari adanya pelatihan ini, sebesar $43 \%$ dan menjawab sangat bermanfaat sebesar 57\% sedangkan yang menjawab pilihan kurang bermanfaat dan tidak bermanfaat sebesar $0 \%$. Selain itu, semua peserta kegiatan menyatakan setuju jika diberikan pelatihan lanjutan sebesar 100\%. Tim juga akan menampung aspirasi mitra jika membutuhkan pelatihan-pelatihan lainnya. Pelatihan lain yang diusulkan oleh peserta kegiatan adalah manajemen keuangan, pemasaran online, cara mempertahankan dan mengembangkan usaha dll.

\section{KESIMPULAN DAN SARAN}

\section{Kesimpulan}

Kegiatan pengabdian masyarakat ini dilakukan atas dasar kepedulian perguruan tinggi terhadap masyarakat sekitar, terutama bagi kalangan wirausaha. Materi yang disampaikan yaitu bagaimana membuat laporan laba rugi dan menggunakannya sebagai salah satu alat evaluasi dan proyeksi usaha.

Sebagian besar peserta masih belum memahami komponen-komponen
DOI: $\underline{\text { https://10.21009/JPMM.002.1.05 }}$

dalam laba rugi dan belum memasukkannya sebagai unsur yang patut diperhitungkan. Pengeluaran untuk usaha masih bercampur dengan pengeluaran rumah tangga menyebabkan laporan laba rugi tidak tepat. Jika informasi tidak tepat, maka keputusan bisnis yang diambil nantinya juga tidak tepat. Keputusan bisnis penting itu diantaranya adalah keputusan dalam menentukan harga jual produk, kuantitas barang yang diproduksi, target penjualan, marjin laba yang diinginkan dll.

Peserta kegiatan ini adalah Ibuibu yang memiliki usaha kecil di Paguyuban Citra Kencana. Sebagian besar peserta tidak memiliki latar belakang pendidikan akuntansi/ekonomi sehingga ketika diberikan materi, mereka membutuhkan waktu yang lebih lama untuk memahami. Praktik akuntansi sederhana mungkin belum bisa dilakukan dengan akurat sesuai standar baku yang berlaku, namun paling tidak dapat memberikan gambaran mengenai kondisi usaha mereka.

Dari hasil evaluasi yang telah disampaiakan sebelumnya, pelatihan ini memberikan dampak baik dari 
pengetahuan mengenai tujuan laporan keuangan maupun peningkatan pemahaman masyarakat tentang pembuatan laporan keuangan terutama laporan laba/rugi. Hasil uji statistik menyatakan bahwa pelatihan berhubungan positif dan signifikan terhadap pengetahuan dan pemahaman pembuatan laporan keuangan peserta kegiatan. Hal ini menjadikan metode pelatihan ini dapat digunakan kembali pada pelaku usaha di area lainnya.

\section{Saran}

Pengetahun tujuan laporan keuangan dan pemahaman pembuatan laporan keuangan merupakan langkah awal dalam kemandirian pelaku usaha dalam melakukan pembukuan. Selanjutnya diperlukan pengawasan konsistensi dari praktek pembuatan laporan keuangan tersebut agar fungsi laporan keuangan sebagai dasar informasi pengambilan dapat dilakukan secara optimal.

\section{DAFTAR PUSTAKA}

Abdul Halim. (2009). Analisis Kelayakan Investasi Bisnis (Kajian dari Aspek Keuangan). Yogyakarta: Graha Ilmu.

Lanen WN., Anderson SW., Maher M.W. (2017). Dasar-dasar
Akuntan Biaya (Adisti Febriyanty dan Jatiningrum, Penerjemah). Jakarta : Salemba Empat.

Kieso, Weygandt, Warfield. (2010). Financial Accounting, IFRS 1st edition. Wisconsin : John Wiley $\&$ Sons.

Riduan. (2012). Belajar Mudah Penelitian untuk GuruKaryawan dan Peneliti Pemula. Bandung: Alfabeta

Romney MB., Steinbart Paul J. (2012). Accounting Information System. USA : Pearson.

Subramanyam KR, Wild J., (2011). Analisis Laporan Keuangan (Dwi Yanti, Penerjemah). Jakarta : Salemba Empat.

Sukirno DS. (2003). Event Study Sebuah Pendekatan. Majalah Informasi 1 : pp 102-115

Zimmerer W., Scarborough N.M.(2008). Kewirausahaan dan Manajemen Usaha Kecil (Deny Arnos Kwary dan Dewi Fitriasari, Penerjemah). Jakarta : Salemba Empat. 